Volume 14. Nomor 1. June 2019 Page 34-44
Pandecta
htt/journal.unnes.ac.id/nju/index.php/pandecta

\title{
Authority of Forestry Police in the Completion Process of Forest Occupation Criminal Acts Cases: Between Expectation And Reality
}

\author{
Diana Lukitasari, Anieq Nisrina Shofwan
}

Universitas Sebelas Maret, Indonesia

DOI: http://dx.doi.org/10.15294/pandecta.v14i1.17179

\begin{abstract}
Article info
Abstrak

Article History:

Received : January 2019

Accepted: June 2019

This research is intended to determine the authority possessed by the forestry police Published: June 2019

Keywords: forest occupation; national park; forestry police related to the crime of forest occupation and how far the implementation of the authority in the process of settling the case of the crime of forest occupation. This research is an empirical criminal legal study, by conducting interviews, direct observation, and literature study. The problem of forest occupation in the area of Alas Purwo National Park is a long-standing problem that can not be solved sooner which can lead to reduced protected areas and disrupt natural ecosystems that already exist around the site of the forest occupation. The existence of citizens who have been found guilty by the court violated Article 78 paragraph (2) jo. Article 50 paragraph 3 sub-paragraph of Law Number 41 of 1999 on Forestry jo. Article 55 paragraph (1) of the Criminal Code (KUHP) related to illegal criminal acts of forest occupation but until this day they still occupy the jungle zone of Alas Purwo National Park area also can disrupt the duties of the forestry police in its efforts to secure the forest. Besides due to the lack of public awareness of the importance of forest existence, the settlement process of forest occupation is also constrained by internal factors of forestry police, namely the understanding of the forestry police on the extent of their authority.
\end{abstract}




\section{INTRODUCTION}

The existence and sustainability of forests has been regulated in such manner as some of the laws and regulations in Indonesia. Article 33 Paragraph (3) of The Constitution of The State of Republic Indonesia 1945 that "Earth and water and natural resources contained therein are controlled by the state and used for the greatest prosperity of the people". From that article we can see that the control and management of forests is left entirely to the state for the achievement of the people's prosperity.

The resources within the forest are explored to sustain the country's life while maintaining the environment. However, current exploration tends to be exploited regardless of the impact and threat of risk that would occur if the forest is damaged. Almost all land in Indonesia is originally a natural forest that is gradually converted by human functions as a form of other land use such as settlement, cultivation, agriculture, plantation, production forest or industrial plant and so on (Widianto et al., 2003: 1).

In fact, most forest areas in Indonesia must have experienced conflict between the public and the state apparatus where their interests collide and touch each other. Yet the success of development in forestry is not only determined by skilled and skilled personnel, but it must also be supported by community participation (Salim, 2013: 122). Some cases are even resolved through court because it is considered preemptive, preventive, and repressive approaches have failed. However, not all cases can end immediately after going through court proceedings.

Causes of forest damage that occurred one of them caused by the occupation of forest areas. The occupation of forest areas discussed in this paper is forest occupation carried out by communities around the forest. According to Article 50 Paragraph (3) sub-paragraph a of Law Number 41 of 1999 on Forestry, "What is meant by occupying the forest area is to control a forest area without obtaining permission from an authorized official, among other things to build residential areas, buildings and other buildings ". Where those who engage in forest occupations pay less attention to the role and function of forests as a buffer for ecosystems.

In order to prevent and limit the destruction of forests, forests area, and forest products, and wild plants and animals caused by human actions, the state has sought the protection of forests through certain forestry officials who are granted special police powers in their fields known as forestry police or abbreviated as polhut. The forestry police according to Article 1 sub-article 2 of Government Regulation Number 60 Year 2009 on Amendment to Government Regulation Number 45 Year 2004 on The Forest Protection is a certain official within the central and regional forestry institutions in accordance with the nature of their work, organizing and or carrying out forest protection efforts the power of law is granted special police authority in the field of forestry and the conservation of biological natural resources and its ecosystem.

Forestry police consist of construction polhut, functional polhut, and perhutani polhut. The implementation of duties and functions of each polhut are regulated by their respective jurisdictions which are divided on the basis of the working area of Satuan Polhut. In Article 4 paragraph (2) of the Minister of Forestry Regulation Number P.75 / Menhut-II / 2014 on The Forestry Police it is mentioned that the implementation of duties and functions of the forestry police can be done preemptively, preventively and repressively. Preemptive activities are activities aimed at preventing, eliminating, reducing, closing the intention of a person or group to commit forestry crimes, such as counseling and guidance to communities around the forest.

Preventive activities are activities aimed at preventing, eliminating, reducing, closing a person's or group's opportunity to commit forestry crimes, such as patrolling forest areas and identifying vulnerabilities, harassment, and threats to forest areas. While repressive activities are non-judicial law enforcement activities to reduce, suppress or stop forestry crimes committed by a person or a group, such as the arrest of suspects in case of being 
caught and law enforcement operation.

However, it appears that the authority given to the forestry police is only halfway. This is like what happened in the case of forest occupation by the community around the forest area in Alas Purwo National Park. Alas Purwo National Park is located in District Tegaldlimo and Purwoharjo, Banyuwangi City, East Java Province. Geographically located at the southeastern tip of Java Island south COast area between $8{ }^{\circ} 26^{\prime} 45^{\prime \prime}-8^{\circ} 47^{\prime} 00^{\prime \prime}$ LS and $114^{\circ} 20^{\prime} 16^{\prime \prime}-114^{\circ} 36^{\prime} 00^{\prime \prime}$ East. Cases of forest occupation in Alas Purwo National Park is rolling since early 2000s that occurred between Alas Purwo National Park with the surrounding forest community (consist of 21 families). People around the forest argue that the land is inherited from his ancestors. But they have absolutely no authentic proof and the facts on the ground suggest otherwise. End of 2013, Alas Purwo National Park brought the case into court. Verdicts issued by courts at the first level or appeal say they are guilty of committing a criminal act of forest occupation.

The case has been awarded a permanent or inkracht legal ruling and the parties considered as provocateurs in committing criminal acts of forest occupation have served their sentences. However, up to the time of this research writer, the people who occupied the Patuk Block Pal 8 Resort Grajagan Purwoharjo Subdistrict in Alas Purwo National Park did not want to voluntarily moved from the location of the conflict. The verdict by the judge is based on the indictment and any evidence in the trial does not have a deterrent effect to the public.

Various efforts have been made by the forestry police that overshadowed Alas Purwo National Park forest area to solve the case, whether it is non-yustisia efforts or the efforts of yustisia. However, in that case repressive measures appear not to be fully implemented. Although a decision has been issued which declares that the community is guilty of committing the criminal act of forest occupation but the forestry police are powerless to expel the forest occupiers from the area because they feel they have insufficient authority. This certainly creates problems of law enforcement, because it causes a legal vacuum (rechtsvacuum) over the location of the conflict.

Looking at the condition, it can be concluded that in addition to the condition of the people around the forest who lack understanding of the importance of the existence of the forest it is also caused by the attitude of the forestry police in carrying out its functions and roles has not been fully optimal. The lack of optimal role and function of the forestry police in implementing law enforcement is caused by their lack of understanding of the authority they possess. The lack of understanding of the forestry police on its own authority as mandated by the special forestry legislation certainly makes the settlement of the criminal case of forest occupation unfinished.

The existence of forests as a buffer for life on Earth can not be denied. Forests are capable of generating oxygen, absorbing pollution, becoming a source of economy, being home to flora and fauna, preventing natural disasters, and many others. However, all the benefits of the existence of the forest of course we can enjoy if the forest is still preserved sustainability. So if there is a case that causes the sustainability of the forest itself to be disturbed should the authorities immediately crack down and immediately resolve it. Because the benefits of forests can not only be enjoyed for now, but also for the future.

\section{PROBLEM STATEMENT}

Based on the above explanations, the problems in this article are focused on:

1. What causes the authority of the forestry police to enforce the law against forest crime occupation is not effective?

2. How is the solution so that law enforcement after the criminal verdict can pressing the forest crime occupation?

\section{RESEARCH METHODS}

The type of research used by the author is empirical or non-doctrinal research 
(social legal research). In this research the author wants to know the circumstances that occur in practice. Empirical legal research is a study based on methods, systematics, and certain thoughts that aim to study one or more specific social phenomena by analyzing them. In addition, also held a deep examination of the social facts to then seek a solution to the problems arising from the symptoms concerned. Data gathering collected by interviews, observation, and literature research to select the important part of Law on the forest law. Data analysis conducted in qualitative technique by legal interpretation and synchronization of the provisions of the related acts.

\section{DISCUSSION AND RESULT}

\section{The Forestry Police Authority in Enforcing Laws Related to The Crime of Forest Oc- cupation}

According to Alam Setia Zain (1997: 54) in his book entitled "Environmental Laws of Forest Conservation" the definition of forestry police is a civil servant within the Ministry of Forestry and other entities assigned full responsibility and responsibility, authority and rights by the center authorized to implement forest product protection. Meanwhile based on Article 1 Paragraph (2) of Government Regulation Number 45 Year 2004 on The Forest Protection, forestry police are certain officials within the central and regional forestry institutions in accordance with the nature of their work, organizing and or carrying out forest protection business by law given special police authority in the field of forestry and conservation of biological natural resources and its ecosystem.

The authority of the forestry police is essentially the right and power granted by the state to certain officials within the central and regional forestry agencies in accordance with the nature of its work to organize and or to undertake forest protection efforts which by lawyers are granted special police powers in the field of forestry and Conservation of biological natural resources and their ecosystem. The granting of authority to the forestry police has been regulated in the articles con- tained in forest-specific legislation.

The rules relating to the authority of the forestry police in the case of the occurrence of the criminal act of self-forestation can be observed in Article 39 of Law Number 5 of 1990 on The Conservation of Biological Natural Resources and Its Ecosystem; Article 51 of Law Number 41 of 1999 on Forestry; Article 31, 35 and 36 of Government Regulation Number 45 Year 2004 on The Forest Protection; Articles 29, 30, 31, 32 and 33 of Government Regulation Number 18 Year 2013 on The Prevention and Eradication of Forest Destruction; Article 4, Article 5 Paragraph (3) Regulation of the Minister of Forestry of The Republic Indonesia Number: P.9 / Menhut-II / 2014 on The Technical Guidelines for the Implementation of Forestry Police Functional Position and Credit Score; and also Article 4, 5, 6, 7, Article 43 Paragraph (1), (3), (4), (5), (6), and (7) Regulation of the Minister of Forestry of the Republic Indonesia Number: P.75 / Menhut-II / 2014 on The Forestry Police.

Based on all the authority possessed by the forestry police related to the crime of forest occupation, the author outlines the group into 2 sections, namely the authority before the issuance of the court decision/verdict and authority after the issuance of the court decision/verdict.

From the Table 1. it can be concluded that the authority of the forestry police in the case of the crime of forest occupation is limited to the action of preliminary investigation and full investigation before a court decision. The premilinary investigation referred to in Article 1 number 5 of the Criminal Procedure Code (KUHAP) is a series of investigative actions to search for and find an alleged criminal incident to determine whether or not an investigation is conducted in accordance with the manner stipulated in this law. Whereas the full investigation itself according to Article 1 Sub-Article 2 of the Criminal Procedure Code (KUHAP) is a series of investigative actions in respect of and in accordance with the manner laid down in this law to seek and collect evidence which by evidence makes light of the criminal offense and to find 
Table 1 . The forestry police in the case of the crime

\begin{tabular}{|c|c|c|}
\hline \multirow{3}{*}{$\frac{\text { Num. }}{1 .}$} & Before The Verdict & After The Verdict \\
\hline & $\begin{array}{l}\text { Conduct an examination of the correctness of reports or state- } \\
\text { ments pertaining to criminal offenses. }\end{array}$ & $\begin{array}{l}\text { Conducting coor- } \\
\text { dinative activities }\end{array}$ \\
\hline & $\begin{array}{l}\text { (Article } 39 \text { Paragraph (3) of Law Number } 5 \text { of } 1990 \text { on The } \\
\text { Conservation of Biological Natural Resources and Its Ecosys- } \\
\text { tem; Article } 30 \text { of Government Regulation Number } 18 \text { Year } \\
2013 \text { on The Prevention and Eradication of Forest Destruction) }\end{array}$ & $\begin{array}{l}\text { which is a synergy } \\
\text { activity between } \\
\text { Polhut units with } \\
\text { Regents / Mayors }\end{array}$ \\
\hline 2. & $\begin{array}{l}\text { Conduct examination of persons or corporation suspected of } \\
\text { committing a crime. }\end{array}$ & and Head of Techni- \\
\hline & $\begin{array}{l}\text { (Article } 39 \text { Paragraph (3) of Law Number } 5 \text { of } 1990 \text { on The } \\
\text { Conservation of Biological Natural Resources and Its Ecosys- } \\
\text { tem; Article } 30 \text { of Government Regulation Number } 18 \text { Year } \\
2013 \text { on The Prevention and Eradication of Forest Destruction) }\end{array}$ & $\begin{array}{l}\text { of Environment and } \\
\text { Forestry in order to } \\
\text { prevent, enforce }\end{array}$ \\
\hline 3. & $\begin{array}{l}\text { Request information and evidence from any person or corpo- } \\
\text { ration related to a crime. }\end{array}$ & $\begin{array}{l}\text { handling cases of } \\
\text { crime. }\end{array}$ \\
\hline & $\begin{array}{l}\text { (Article } 39 \text { Paragraph (3) of Law Number } 5 \text { of } 1990 \text { on The } \\
\text { Conservation of Biological Natural Resources and Its Ecosys- } \\
\text { tem; Article } 36 \text { Paragraph (2) of Government Regulation Num- } \\
\text { ber } 45 \text { Year } 2004 \text { on The Forest Protection; Article } 30 \text { of Gov- } \\
\text { ernment Regulation Number } 18 \text { Year } 2013 \text { on The Prevention } \\
\text { and Eradication of Forest Destruction; Article } 7 \text { Paragraph (2) } \\
\text { Regulation of the Minister of Forestry of the Republic Indone- } \\
\text { sia Number: P.75 / Menhut-II / } 2014 \text { on The Forestry Police) }\end{array}$ & $\begin{array}{l}\text { Article } 43 \text { Para- } \\
\text { graph (4), (5), (6), } \\
\text { and (7) Regula- } \\
\text { tion of the Minister } \\
\text { of Forestry of the } \\
\text { Republic Indone- } \\
\text { sia Number: P.75 / } \\
\text { Menhut-II / } 2014 \text { on }\end{array}$ \\
\hline 4. & Conduct checks, searches, and seizure of evidence relating to & The Forestry Police) \\
\hline
\end{tabular}

(Article 39 Paragraph (3) of Law Number 5 of 1990 on The Conservation of Biological Natural Resources and Its Ecosystem; Article 51 Paragraph (2) of Law Number 41 of 1999 on Forestry; Article 30 of Government Regulation Number 18 Year 2013 on The Prevention and Eradication of Forest Destruction)

5. Take photographs and / or record through portrait and / or tape recorder on people, goods, transportation means, or anything that can be used as evidence of crime.

(Article 30 of Government Regulation Number 18 Year 2013 on The Prevention and Eradication of Forest Destruction)

6. Conduct examination in certain places suspected of evidence, bookkeeping, recording, and other documents as well as confiscation of materials and articles of proceeds of crime that may be used as evidence.

(Article 30 of Government Regulation Number 18 Year 2013 on The Prevention and Eradication of Forest Destruction)

7. Ask for expert assistance in order to carry out investigative tasks.

(Article 30 of Government Regulation Number 18 Year 2013 on The Prevention and Eradication of Forest Destruction) 
8. Create and sign news and other letters related to criminal investigation.

(Article 39 Paragraph (3) of Law Number 5 of 1990 on The Conservation of Biological Natural Resources and Its Ecosystem; Article 30 of Government Regulation Number 18 Year 2013 on The Prevention and Eradication of Forest Destruction)

9. Stopping an investigation in the absence of sufficient evidence of a criminal offense.

(Article 39 Paragraph (3) of Law Number 5 of 1990 on The Conservation of Biological Natural Resources and Its Ecosystem; Article 30 of Government Regulation Number 18 Year 2013 on The Prevention and Eradication of Forest Destruction)

10. Inform the commencement of the investigation and report the results of its investigation to the Prosecutor through the Police Investigation Officer of the Republic Indonesia.

(Article 39 Paragraph (4) of Law Number 5 of 1990 on The Conservation of Biological Natural Resources and Its Ecosystem; Article 30 of Government Regulation Number 18 Year 2013 on The Prevention and Eradication of Forest Destruction)

11. Investigate, in order to find and arrest the suspect at the direction of the leader.

(Article 36 Paragraph (3) of Government Regulation Number 45 Year 2004 on The Forest Protection)

12. Make arrests, detentions, searches, and seizures.

(Article 30 of Government Regulation Number 18 Year 2013 on The Prevention and Eradication of Forest Destruction)

13. Guard against suspects, witnesses or evidence.

(Article 7 Paragraph (2) Regulation of the Minister of Forestry of the Republic Indonesia Number: P.75 / Menhut-II / 2014 on The Forestry Police)

14. In case of being caught red-handed, it is mandatory to arrest the suspect to be handed over to the authorities.

(Article 51 Paragraph (2) of Law Number 41 of 1999 on Forestry; Article 36 Paragraph (2) of Government Regulation Number 45 Year 2004 on The Forest Protection)

15. Request information and evidence from a person or entity in connection with a criminal offense in the field of conservation of living natural resources and their ecosystem.

(Article 39 Paragraph (3) of Law Number 5 of 1990 on The Conservation of Biological Natural Resources and Its Ecosystem)

16. Call people to be heard and examined as suspects or witnesses. (Article 30 of Government Regulation Number 18 Year 2013 on The Prevention and Eradication of Forest Destruction) 
the suspect.

The forestry police basically have the same authority as the the police of Republic Indonesia in relation to enforcing the criminal law, namely as preliminary investigator and full investigator. However, preliminary investigation and full investigation by forestry police may be limited to criminal offenses set out in forest-specific legislation. In conducting the preliminary investigation and full investigation, the forestry police must notify the commencement of the investigation and report the results of its investigation to the Prosecutor through the Officials of the Police Investigator of the Republic Indonesia (Article 39 paragraph (4) of Law Number 5 of 1990 on The Conservation of Biological Natural Resources and Its Ecosystem).

After the issuance of criminal verdict on the crime of forest occupation, the authority possessed by the forestry police is to make coordinative efforts between forestry police units in synergy with the Regents / Mayors and Head of Technical Implementation Unit (UPT) Ministry of Environment and Forestry to prevent, crack down and enforce the law on acts cases (Article 43 paragraph (3) and (5) Regulation of the Minister of Forestry of the Republic Indonesia Number: P.75 / MenhutII / 2014 on The Forestry Police). The forestry police have absolutely no executive authority. As for the meaning of the authority of the executor is the authority to execute a court decision that has a permanent legal force or inkracht.

Lawrence Meir Friedman in his theory of Three Element of Legal System said that the effectiveness of law enforcement depends on three elements of the legal system, namely, substance, structure, and legal culture (Achmad Ali, 2002: 7). If one of these elements is not fulfilled, then law enforcement will not run effectively. Substance referred to here is legal rules, while structure mean the implementation or enforcement of law by state apparatus and legal culture is the culture or habits of the community in response to the existence of the law. Legislation in Indonesia has actually regulated the criminal acts of forest occupation, both in terms of understan- ding and sanctions. However, in the case of criminal acts of forest occupation occurring in Alas Purwo National Park, the implementation of the law by the state apparatus did not go well. There is no good coordination between the relevant state apparatus. Added with the habits of the people who often ignore or ignore the law itself causes what has been regulated by law regarding forest occupation to be in vain.

It has been mentioned in the previous table that the authority of the forestry police after the issuance of criminal decisions is limited to conducting coordinative efforts with other state apparatuses that have similar interests. In connection with the case examined by the author regarding the conflict between the Alas Purwo National Park Hall and the surrounding forest communities that occupy the forest, in this case what the forestry police can do is coordinate efforts between the forestry police unit in Alas Purwo National Park with the Banyuwangi Regent as the highest executive officer in Banyuwangi Regency and Head of the Unit (UPT) Ministry of Environment and Forestry of Banyuwangi Regency. The results of the synergy of the apparatus are expected to be able to mediate a prolonged conflict so that the people occupying the Patuk Block Pal 8 Grajagan Resort Purwoharjo District can leave the location. This authority can certainly be carried out optimally if there has been a good synergy between stakeholders. Even though the synergy between the stakeholders of the state apparatus is absolutely necessary as a form of bureaucratic reform efforts that have been encouraged by the central government.

Back again to the fact that the law itself also has limitations in its effectiveness as stated by Anthony Allot in his theory, The Limit of Law. He said that the law would be effective if its purpose and application could prevent undesirable actions and eliminate chaos (Anthony Allot, 1980: 287). Effective law can generally make what is designed by the maker can be realized in social life in the community. If there is a failure or a condition in which the law must be implemented or implemented in a new situation, the repair or 
correction will be resolved again by the law itself easily. In this case the legal rules that have been designed by the legislators cannot prevent acts of forest occupation crime carried out by communities around the forest and cannot eliminate the chaos resulting from the crime. So that it can be said that the legal rules governing criminal acts of legal occupation are not as effective as expected by the makers.

\section{Implementation of Forestry police Author- ity in Law Enforcement Process After Re- lease of Criminal Verdict Related to Forest Crime Occupation}

Forests are one source of wealth for the state and society if it can be managed and maintained properly. However, forests can also be disastrous if they are not maintained and conserved in an appropriate way. The state through the government has established a number of areas to be a protected forest area in order to maintain the balance of existing ecosystems. Maintenance and security of forest areas that have been established by the state requires cooperation between the public and the state apparatus. In this case the state has delegated part of its authority over the protection and protection of forest areas to forestry police units.

The author conducted an interview with Mr. Cipto as the Forestry police Coordinator at Alas Purwo National Park and Mr. Bagyo, Mr. Joko, Mr. Iqbal, and Mr. Azzam as members of the Forestry Police Unit on 21-28 March 2017 at the Office of Alas Purwo National Park Banyuwangi. According to Mr. Cipto, residents began to occupy the site of conflict in the forest area of Alas Purwo National Park since early 2000. The location they occupied covers the area of Patuk Block 8 Resort Grajagan SPTN Region I Tegaldlimo Purwoharjo District with coordinates $8^{\circ}$ 35'33.4 "LS And 114²13'55.1 “BT.

Alas Purwo National Park has tried to make persuasive approach by cooperating through vertical institution, by reporting it to the village and sub-district, and doing the consultation with the community. The forestry police have also attempted to socialize the status of the land they occupy, which is a jungle zone in the forest area of Alas Purwo National Park. According to Article 7 paragraph (2) of Regulation of the Minister of Forestry Number: P. 56 / Menhut-II / 2006 on The National Parks Zoning Guideline, the jungle zone should not be used for community housing development or used as agricultural land and livestock. The permissible development is the development of facilities and infrastructure for the purposes of research, education, and limited natural attractions. However, the whole effort of the approach did not work.

The absence of good response from the community has made the park also conducted mediation efforts by bringing together Village Leadership Meeting (Muspida) and City Leadership Meeting (Muspika) of Banyuwangi, but the mediation process did not find the middle point. Because it is perceived that the socialization and mediation that has been attempted does not give maximum results, the park also issued an ultimatum to the community to leave the conflict location immediately. However, the people simply rejected it. This rejection from the community is included in the theory of factors that influence law enforcement according to Soerjono Soekanto. This theory explains that every society has the legal consciousness, the question that arises is the level of compliance with the law, that legal compliance is high, moderate, or less (Soerjono Soekanto, 2004: 42). The community has been informed of the prohibition on occupying forests by forestry police and understanding regulations but not complying it. The forestry police at Alas Purwo National Park Office, which overshadows the conflict site, will certainly clarify the legal status of the forest area. Finally the new National Park took him to court on the end of 2013.

In its efforts to bring the case to justice, the forestry police unit of Alas Purwo National Park Authority has exercised its authority as a well-informed investigator and investigator in the case of the crime of forest occupation. They collect evidence and witnesses that can support the categorization of the community's actions as a criminal act of fo- 
rest occupation. Finally after going through the process of preliminary investigation and full investigation, got 4 suspects indicated as provocateurs to commit the crime of forest occupation. They are prosecuted on the grounds of Article 78 paragraph (2) jo. Article 50 paragraph 3 sub-paragraph a of Law Number 41 Year 1999 on Forestry jo. Article 55 paragraph (1) of the Criminal Code (KUHP) related to the crime of forest occupation. The four men are Sutrisno, Sarniyanto, Aris Tuasikal, and Sugiyanto. However, Aris Tuasikal and Sugianto are still included in The List of People Search (DPO) of Banyuwangi Resort Police until now.

The Banyuwangi District Court ruled that the defendants were found guilty of proven criminal acts of forest occupation and imprisonment of 5 (five) months imprisonment respectively and a fine of Rp. 200.000, - (two hundred thousand rupiah), provided that if the fine is not paid then it is replaced with imprisonment each for 1 (one) month. The guilty party is not satisfied with the decision of the first judge and finally appealed to the Surabaya High Court. The appeal verdict also reinforces the decision of the court of first instance.

After the court's decision, the two defendants went through the process of detention and paid the fine as imposed. However, until now after the verdict of the court that has permanent legal force, the people who built the house and manage the farmland in Block Patuk Pal 8 Alas Purwo National Park area is still not willing to leave. They even seek to recognize "indigenous peoples" from both local and central government. Meanwhile, the Alas Purwo National Park through the forestry police who has pocketed two (2) court decisions that have been inkracht dare not take over the territory because it feels no authority.

The theory that is described by G. Peter Hoefnagels is closely related to forest crime occupation, namely the theory of criminal policy. Criminal Policy is a policy of designating human behavior as crime (Barda Nawawi Arief, 2002: 45). One rational effort from the government and society in prevention is done by criminal law application (penal), prevention without punishment (non-penal) and influencing views of society on crime and punistment/mass media. The concept emphasizes efforts to approach handling the causes of crime as part of a social problem directly and indirectly can cause flourishing of crime.

In the case investigated by the authors, as explained earlier that the National Park Authority of Alas Purwo through its forestry police unit has attempted to make prevention without punishment (non-penal) with preemptive, preventive and repressive efforts against the people who committed the crime of forest occupation in Patuk Block 8 Resort Grajagan SPTN Region I Tegaldlimo Purwoharjo District . However, because all non-judicial efforts are not at all knocked their consciousness to move away from the location of the conflict then the forest police unit of Alas Purwo National Park Office filed the case to court. People argue that the land they occupy is the land of their ancestors long before Indonesia was colonized by the Dutch. However, according to Mr. Cipto, when the Dutch colonized Indonesia the Dutch have expelled the people who inhabit the location because the Dutch want to make it as a wildlife reserve area. Determination of the area into South Banyuwangi Wildlife Sanctuary has also been established based on the Decree of the Governor General of Dutch Indies No. 6 stbl 456 dated 01 September 1939 with a total area of 62,000 ha.

So according to the national park related to the public recognition that the location of the conflict is the land of their ancestral heritage is just a false opinion. Because they have no written evidence or other strong evidence of ownership of the location of the conflict. As for one of the evidences they presented to the previous trial was the existence of a grave that was recognized as the grave of their ancestors who were around the site of the conflict. The tomb was originally marked with a black stone that stood upright without any writing. But when the authors do research, around the tomb has been built a burial complex in the form of the ark and became 
one of the objects that were saved.

The existence of forestry police as an extension of the state assigned to protect the forest area is not respected by the communities surrounding the conflict area. They intimidate a number of forestry police who handle the case. Even students who want to do research at the site also had experienced intimidation from the community when they want to take data from the field. Intimidation is done in various ways, such as threatening by using sharp weapons and using the things that are heresy.

However, according to the authors of the implementation of the authority of the forestry police unit of Alas Purwo National Park after the verdict of law enforcement remains not as optimal as the exercise of authority before the issuance of the verdict. Forestry police units dare not take over the territory because it feels no authority. This indicates that they are not optimizing their authority to enforce the criminal law properly.

The existence of the authority of the forestry police to conduct coordinative efforts after the issuance of criminal verdict related to the case should make the Alas Purwo National Park through its forestry police immediately coordinate with Regent of Banyuwangi and Head of Technical Implementation Unit (UPT) Ministry of Environment of Banyuwangi Regency. This coordination will be able to discuss how efforts should be made to the communities that commit the crime of forest occupation, whether to be forced evictions or to relocate to a more suitable location for occupancy. Ministry contributions are also needed by making policies that regulate executorial authority to forest police in implementing court decisions. The result of such coordination and regulation is expected to end the long conflict between forestry police and the people who commit the criminal act of forest occupation so that the conservation of the jungle zone will proceed as it should.

\section{CLOSING}

Forest occupation is a form of exploitation of forest areas deliberately carried out by a person or a person without obtaining permission from the authorities. If the action of forest occupation continues to continue it will have a negative impact on the sustainability and sustainability of the forest itself. If the forest area is damaged caused by human hand act then the surrounding environment will also experience disturbance and even damage. Based on this research, the authors know that implementation of forestry police authority related to the crime of forest occupation by forestry police unit of Alas Purwo National Park Office has not been fully implemented optimally. This is due in part to their lack of understanding of their authority as mandated in the special forestry legislation. Lack of optimizing the roles and functions of the forestry police can certainly lead to a delay in the settlement of cases of criminal acts of forest occupation.

Furthermore, the forestry police unit should to have understand the authority of prosecuting and enforcing law in the forestry sector in general and the crime of forest occupation in particular. Activities that can be done one of them by holding a socialization about the task, authority, and responsibility by bringing the expert interpretation in the field of law. In order for Alas Purwo National Park and Banyuwangi Regent and Head of Technical implementation Unit (UPT) Ministry of Environment and Forestry of Banyuwangi Regency to form a special joint unit consisting of representatives from them. The unit will have its own hotline as a means of public complaints regarding the existence of criminal acts in the field of forestry. In addition, this unit also has a duty to hold socialization to the community as an effort to minimize the occurrence of criminal acts in the field of forestry. Coordination among relevant agencies within this particular joint unit will also be expected to find the final solution of any forest crime case that has obtained a permanent legal ruling.

\section{REFERENCES}

\section{Books:}

Ali, A. (2002). Keterpurukan hukum di Indonesia: penyebab dan solusinya. Ghalia Indonesia.

Allott, A. N. (1980). The limits of law (p. 216). London: 
Butterworths.

Arief, B. N., \& Arief, B. N. (1996). Bunga rampai kebijakan hukum pidana. Citra Aditya Bakti.

Nurrochmat, D. (2005). Strategi pengelolaan hutan: Upaya menyelamatkan rimba yang tersisa. Pustaka Pelajar.

Purwo, B. T. N. A. (2016). Buku Informasi Balai Taman Nasional Alas Purwo. Banyuwangi (ID): Balai Taman Nasional Alas Purwo.

Salim, H. S. (2003). Dasar-dasar hukum kehutanan. Sinar Grafika.

Soekanto, S. (2006). Pengantar penelitian hukum. Penerbit Universitas Indonesia (UI-Press).

Soekanto, S. (2004). Faktor-Faktor Yang Mempengaruhi Penegakan Hukum. Raja Grafindo Persada, Jakarta.

Widianto, dkk, (2003). Fungsi dan Peran Agroforestry, World Agroforestry Centre (ICRAF), Southeast Asia Regional Office, Bogor.

Zain, A. S. (1996). Hukum Lingkungan Konservasi Hutan. Penerbit Rineka Cipta. Jakarta.

Papers:

Mulyana, B. (2015). Problematika PPNS Kehutanan Balai Besar Taman Nasional Gunung Gede Pangrango dalam Penegakan Hukum Tindak Pidana Perambahan. Hukum dan Pembangunan Ekonomi, 5.

Suratmo, F., Gunarwan. (2001). The Strategy To Stop Degradation Of Tropical Rain Forest In Indonesia And How To Improve The Condition. Journal of Tropical Forest Management, 7(1): 15-22

\section{Regulations:}

Criminal Code (KUHP)
Criminal Procedure Code (KUHAP)

The Constitution of The State of Republic Indonesia 1945

Law Number 5 of 1990 on The Conservation of Biological Natural Resources and Its Ecosystem

Law Number 41 on 1999 on Forestry

Law Number 19 Year 2004 regarding Stipulation of Government Regulation in Lieu of Law Number 1 Year 2004 on Amendment to Law Number 41 Year 1999 concerning Forestry

Law Number 18 Year 2013 on The Prevention and Eradication of Forest Destruction

Government Regulation Number 45 Year 2004 on The Forest Protection

Government Regulation Number 60 Year 2009 on Amendment to Government Regulation Number 45 Year 2004 on The Forest Protection

Regulation of the Minister of Forestry of the Republic Indonesia Number: P.9 / Menhut-II / 2014 on The Technical Guidelines for the Implementation of Forestry Police Functional Position and Credit Rate

Regulation of the Minister of Forestry of the Republic Indonesia Number: P.75 / Menhut-II / 2014 on The Forestry Police

\section{Documentations:}

Verdict of Banyuwangi City Court Number: 954/Pid. Sus/2013/PN.Bwi.

Verdict of Surabaya High Court Number: 121/ PID/2014/PT.SBY. 